\title{
The Innovation Value Chain of Outbound Open Innovation: Theoretical Extension and Case Study
}

\author{
Ailing Yan ${ }^{1, a^{*}}$, Hong Jiang ${ }^{2, b}$ \\ ${ }^{1}$ School of Business Administration, Zhejiang Gongshang University, Hangzhou, China \\ ${ }^{2}$ Institute of Policy and Management, Chinese Academy of Sciences, Beijing, China \\ a*alyan@foxmail.com, bjohncn@foxmail.com
}

\begin{abstract}
Keywords: Outbound Open Innovation, Innovation Value Chain, Desorptive Capacity, Knowledge Creation, Case Study

Abstract: Open innovation is the focus of academic attention. As one type of open innovation, outbound open innovation (OOI) is central to the survival and growth of firms, and ultimately to the health of the economies of which they are part especially in the era of knowledge economy. This study demonstrates the use of innovation value chain (IVC), a conceptual framework and modeling tool, through constructing the IVC of OOI, which reveals the operation mechanism of desorptive capacity and provides a theoretical basis for implementing OOI.
\end{abstract}

\section{Introduction}

The pressures of globalization have forced firms around the world to change their innovative ways. For years, firms have relied on the closed innovation model to be competitive and bring new product and services to the market (Chesbrough, 2006) ${ }^{[1]}$. Chesbrough and Crowther (2006) ${ }^{[2]}$ define two types of open innovation that companies may engage in: inbound open innovation (IOI) and outbound open innovation (OOI). In OOI, companies do not only rely on internal paths to market, but also look for external organizations so as to better commercialize a given technology.

\section{Conceptual Background and Literature Review}

Traditionally, most industrial firms focused on internally developing new technologies and applying them in their own products (Calantone and Stanko, 2007) ${ }^{[3]}$. However, research on open innovation highlights that not all good ideas come from inside the organization (Laursen \& Salter, 2006) ${ }^{[4]}$. Open innovation represents a newly emerging business model across a wide range of industries, enabling an 'open' flow of internal and external expertise to break through companies barriers so as to enhance innovation and commercialization success. The open innovation paradigm involves both inflows of knowledge to accelerate internal innovation and outflows of knowledge to pursue external paths to market for proprietary innovations (Chesbrough et al., 2006) ${ }^{[5]}$. Therefore, there are basically two ways in open innovation: the inbound process, which exploits external sources of innovation in order to integrate external know-how and innovation into the company, and the outbound process, which utilizes external innovation opportunities with internal capabilities and resources.

The outbound process, named OOI by Chesbrough and Crowther $(2006)^{[2]}$, refers to the practice of establishing relationships with external firms with the purpose to commercially exploit technological opportunities. The practice of OOI often takes the form of out-licensing agreements (Anand and Khanna, 2000 $)^{[6]}$, which involves the exchange of knowledge disembodied from products in the form of technologies, patents, know-how ideas. However, prior open innovation research has focused on IOI, i.e., acquiring external technology (Van de vrande et al., 2009) ${ }^{[7]}$. By contrast, the recent increase in OOI is a trend from practice, which has been relatively neglected by academic research (Lichtenthaler and Ernst, 2007) ${ }^{[8]}$. By way of OOI, firms attempt to achieve monetary and strategic opportunities. Regarding monetary benefits, several pioneering firms, e.g., Texas Instruments, generated hundreds of millions of dollars in annual licensing revenues (Rivette and Kline, 2000) ${ }^{[9]}$. The practice of OOI is increasingly regarded as a strategic activity by firms, which can profit from their own innovations 
without investing in complementary assets (Teece, 1986) ${ }^{[10]}$. Not only small firms whose main business is to generate and sell technologies, make extensive of OOI practices, but also large corporations such as IBM and Dupont have started to generate additional revenues from the out-licensing of their knowledge assets (Chesbrough, 2003) ${ }^{[11]}$. From the above analysis, it is obvious that the OOI can really improve enterprise performance. Consequently, it is necessary to figure out how OOI create value for those companies, which is a very sophisticated problem and have not been make an in-depth analysis by previous researchers. In order to unravel this 'mystery', it is feasible to introduce the innovation value chain (IVC) to unlock the 'secrets'.

Innovation is a variety of roles intertwined, and a complex process of intervention. The innovation process is poorly understood, and at the same time innovation is being enveloped in an unobservable "black box". Subsequently, Hansen \& Birkinshaw (2007) ${ }^{[12]}$ and other scholars introduced the idea of Porter's value chain and regarded the knowledge commercialization of the innovation process as a flow value chain, which includes three main components: knowledge production, knowledge transfer and knowledge diffusion. So far the understanding for the essence of the innovation process has been greatly enriched and the "black box" of the innovation process seems to have been gradually open.

\section{Modelling Framework}

Firms may open up their innovation processes on two dimensions. While IOI refers to the acquisition of external technology in open exploration processes, OOI describes the outward transfer of technology in open exploitation processes. It goes without saying that OOI can bring huge gains for the enterprise. However, unit now how OOI creates value for the enterprise has not been discussed in detail. This study attempts to draw on the IVC tools to elaborate the value creation process of OOI. Based on Roper et al. $(2008)^{[13]}$ who have divided IVC into three stages and the characteristics of the OOI process, in order to explore the "black box" , this study creatively divides the IVC of OOI into three stages (see Fig.1): knowledge creation, knowledge output and knowledge control,.

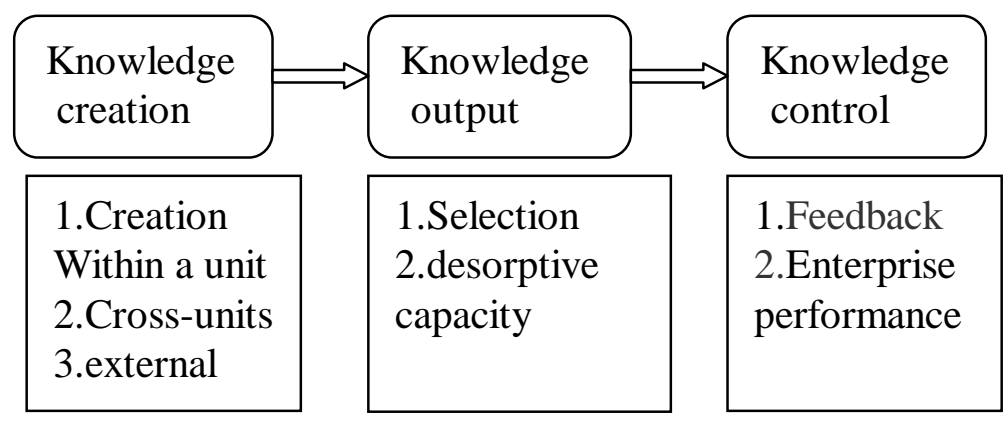

Fig.1. The flow chart for the IVC of OOI.

Knowledge creation is a continuous, self-transcending process through which one transcends the boundary of the old self into a new self by acquiring a new context, a new view of the world, and new knowledge. In short, it is a journey 'from being to becoming'. Nonaka, Toyama and Konno(2000) start from the view of an organization as an entity that creates knowledge continuously, and their goal is to understand the dynamic process in which an organization creates, maintains and exploits knowledge ${ }^{14}$. In the knowledge output stage, enterprise own technology will be transferred to the outside of organizations boundaries. The most common application of knowledge is to transfer or sale knowledge as product, thereby to obtain the knowledge value. In knowledge control stage, enterprise performance is improved through knowledge control. Finally, the effect path of OOI on enterprise performance is summed up. In this three stages, each stage affects firm's desorptive capacity, thereby to improve enterprise performance (see Fig. 2). So, in each stage of the IVC of OOI, influential factors will affect the level of firm's desorptive capacity. 


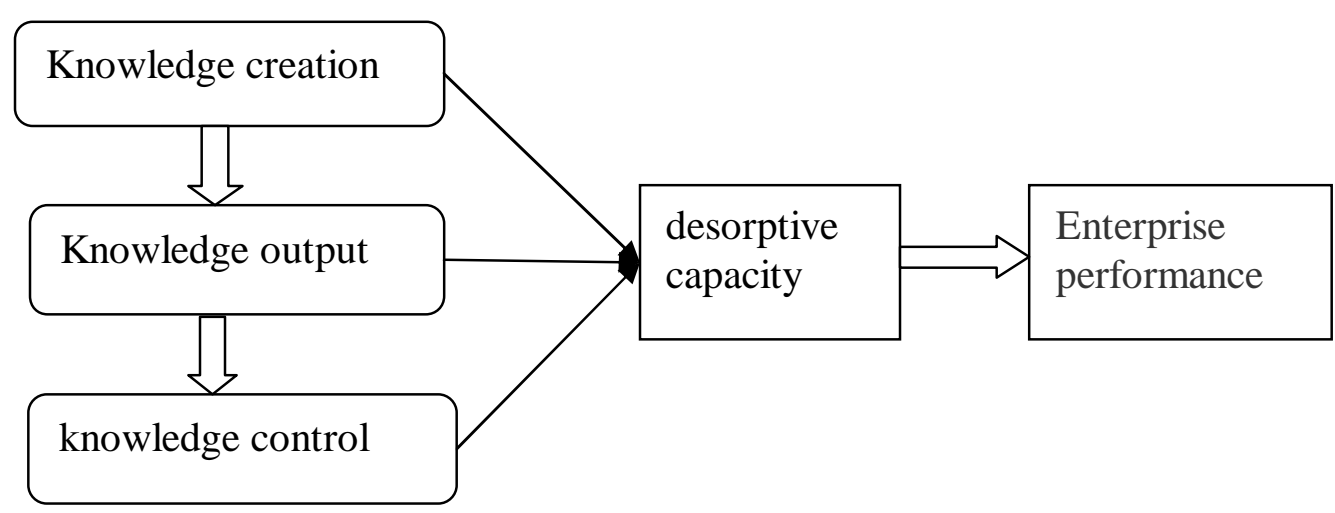

Fig. 2. The IVC of OOI framework.

\section{Case Study}

HW, which was built in 1987, is the world's largest telecommunications network solutions provider. It has built eight regional headquarters and 55 representative offices and technical service centers in the world. Facing fierce competition, HW has to attach great importance to the independent technical route from the outset and continuously implement innovation.

In recent years, HW's R\&D expenditure is more than 100 million RMB. As a consequence, more and more advanced engineers came to HW, which helped HW achieve a large increase in new product development. Nevertheless, this positive trend merely continued in a shorter time. When the competition became fiercer, the road to innovation became more rugged than before. Performance growth had become increasingly slow, even though HW put more money and human resource into R\&D activity. From then on, HW changed its strategy and started to build an external network, which included both competitors and partners working together to create a good living space, so as to share the interests of the value chain. In terms of technology, HW cooperated with world-class companies (such as Intel, Microsoft and IBM, etc.) and established a joint laboratory. In the joint laboratory, the staff from different companies worked together to transfer knowledge, not only outputting their own knowledge to other enterprises, but also acquiring knowledge from other enterprises. In this process, HW performed both IOI practices and OOI practices.

At the end of December 2009, HW joined the 123 standards organizations such as the ITU, 3GPP, 3GPP2 and IEEE, etc., and served in these standards organizations. Thereafter HW actively participated in international standard-setting and has submitted more than 18,000 articles to the standards organizations by the end of 2011, which had a positive impact on the setting of standards. In this process, HW's outward knowledge output is obvious. The OOI practices brought huge income for HW, which mainly reflects in that 2010 contract sales of HW reached to $\$ 34$ billion. The patents number of HW grew so rapidly that foreign manufacturers cannot ignore it. An important work of HW's Intellectual Property Department is to patent cross-licensing through negotiations. HW has achieved patent cooperation agreements with Qualcomm, Ericsson, Nokia, Siemens, Motorola, 3Com and other leading manufacturers. It is also a clear trend to combine the patent with standards in order to obtain benefits. The industrial standard has a certain mandatory increasingly used by foreign manufacturers so as to consolidate its intellectual property monopoly power. It is necessary to comply with international standards in production. HW has more than 200 part-time employees engaging in standard work. HW's patents and standards development process completely demonstrated that China's companies have the ability to catch up with advanced level in the world and become a dominant force.

According to the case study, we might separate the OOI of HW into three stages, including knowledge creation and knowledge output and knowledge control. In the Knowledge creation stage, HW constantly created knowledge by increasing R\&D expenditure. In the knowledge output stage, HW output knowledge through establishing a joint laboratory with external organizations, actively participating in international standard-setting, as well as cross-licensing activities between enterprises. 
In knowledge control stage, HW improved the technological innovation capability and realized the value creation of knowledge by tracking and feedback on the output of the technology and knowledge.

\section{Conclusions}

In previous research and practice, the importance of OOI was ignored and the complete operation mechanism of OOI has not been revealed. Through constructing the IVC of OOI, this study reveals the operation mechanism of desorptive capacity, and provides a theoretical basis for implementing OOI. Based on the relevant research literature derived from logical reasoning, this study constructs an framework for IVC of OOI and provides a case to support it. In subsequent research, through empirical data, it may further verify the operation mechanisms of the IVC of OOI so as to provide advice for enterprise practices of OOI.

\section{References}

[1] Chesbrough, H. Open Business Models: How to Thrive in the New Innovation Landscape. Boston: Harvard Business School Press(2006).

[2] Chesbrough, H., and A. K. Crowther. "Beyond High Tech: Early Adopters of Open Innovation in Other Industries,” R and D Management, 2006, 36(3), 229-236.

[3] Calantone, R.J. and Stanko, M.A. Drivers of outsourced innovation: an exploratory study. Journal of Product Innovation Management, 2007, 24, 230-241.

[4] Laursen, K., \& Salter, A. Open for innovation: The role of openness in explaining Innovative performance among UK manufacturing firms. Strategic Management Journal, 2006, 27:131-150.

[5] Chesbrough, H., W. Vanhaverbeke, and J. West, Eds. Open Innovation:Researching a New Paradigm. New York: Oxford University Press(2006).

[6] Anand, B. N. and Khanna, T. The structure of licensing contracts. Journal of Industrial Economics, 2000,48, 103-135.

[7] Van De Vrande, V., J. P. J. De Jong, W.Vanhaverbeke, and M. De Rochemont. “Open Innovation in SMEs:Trends, Motives and Management Challenges," Technovation 2009,29(6-7),423-437.

[8] Lichtenthaler, U. and Ernst, H. External technology commercialization in large firms: results of a quantitative benchmarking study. R\&D Management, 2007,37, 383-397.

[9] Rivette, K.G. and Kline, D. Rembrandts in the Attic: Unlocking the Hidden Value of Patents. Boston: Harvard Business School Press(2000).

[10] Teece, D.J.. Profiting from technological innovation: implications for integration, collaboration, licensing and public policy. Research Policy, 1986,15, 285-305.

[11 ] Chesbrough, H. W. Open innovation: The new imperative for creating and profiting from technology. Boston: Harvard Business School Press 2003.

[12] Hansen, M.T., Birkinshaw, J., The innovation value chain, Harvard Business Review, 2007, 85(6): 121-130.

[13] Roper, S., Du, J., Love, J.H., Modelling the innovation value chain, Research Policy, 2008, 37(6/7): 961-977.

[14] Nonaka, I., Toyama, R., Konno, N. (2000) SECI, Ba and Leadership: a Unified Model of Dynamic Knowledge Creation, Long Range Planning, Vol. 33(2000), Elsevier Science L. 